\title{
THE FORMATION AND ACTIVITY \\ OF YOUTH RESISTANCE ORGANIZATIONS IN SOVIET-OCCUPIED LITHUANIA
}

\section{JUOZAPAS ROMUALDAS BAGUŠAUSKAS}

Archive of Lithuanian Social Organizations, Vilnius

The investigation of youth resistance to the Soviet regime in Lithuania is an important part of the nation's history. This problem is closely associated with other political and social issues concerning the development of society.

Special studies of these problems could not be conducted during the Soviet period due to the political considerations of that time; those studies which were made merely reflect the attempts of Communist structures to exploit the youth for their own ends. At that time youth resistance to the occupation regime was researched in greater detail only by foreign authors. Thus, in his analysis of the youth movement in the Baltic countries, Peter J. Babris ${ }^{1}$ dealt not only with the activity of the Komsomol, but with the questions of youth resistance. However, in his studies he did not quite take into consideration the fact that the Young Communist League was not a Baltic youth organization, but merely a tool of the occupation regime in its attempts to consolidate its existence in these countries. He was not fully aware of the difference between the aspirations of Russian youth and those of the young people in the countries, occupied by the Soviet Union.

The problems of the Sovietization of Lithuanian youth and its, resistance were dealt with by Lithuanian historians and public figures living in exile. ${ }^{2}$ Many of these publications, however, were not intended specially to research the history of youth resistance - the activity of young people was dealt with only as a part of the

${ }^{1}$ P. J. Babris. Youth Under Communism. Arlington Heights, Ill., Research Publishers, 1967.

${ }^{2}$ Vytautas Alantas. Romas Kalanta. Gyvieji Deglai Nemuno slenyje. Cleveland: Viltis, 1976; Laisvès ilgesio prasiveržimai. I Laisvę, no. 55, 1972, 50-52, ff. 
general freedom movement of the Lithuanian people. ${ }^{3}$ Valuable generalizations related to youth resistance to the regime can be found in the Lithuanian underground press.

After the re-establishment of Lithuanian independence, research into Sovietization and resistance became more intensive. Many papers and documents dealing with youth participation in resistance to the Soviet regime appeared in Lituanica, ${ }^{4}$ Lietuvos archyvai, ${ }^{5}$ Laisves kovu archyvas, ${ }^{6}$ in the publications of the Institute for the Research of the Genocide and Resistance of the Lithuanian Population (the Genocide and Resistance Research Centre of Lithuania), ${ }^{7}$ and the first memoirs of the participants were issued. ${ }^{8}$ These publications contain some generalizations of the movement - documentary materials, statistical data relating to the membership, its social structure and the analysis of the activity of some organizations. However, all that is only the beginning of the research, so far dealing only with particular periods and particular organizations.

The aim of this paper is to reveal the features of the formation and activity of youth resistance structures on the basis of the reminiscences of the participants themselves, the results of other research and hitherto unpublished materials kept in the Archive of Lithuanian Social Organizations, the Lithuanian Extraordinary Archive and Lithuanian Central State Archive.

The main subject of research into resistance problems is youth organizations and their activities. Following the

${ }^{3}$ Juozas Brazaitis.Vienu vieni. Vilnius, 1990; Kęstutis Girnius. Partizanu kovos Lietuvoje. Vilnius: Mokslas, 1990; Lithuania 700 Years. Ed. by Albertas Gerutis. New York, N.Y., 1969; Tomas Remeikis. Opposition to Soviet Rule in Lithuania. 1945-1980. Chicago, Ill., Institute of Lithuanian Studies. 1980.

${ }^{4} \mathrm{~J}$. Bagušauskas. Antisovietinio pasipriešinimo organizacijos Lietuvoje 1954-1960 metais. Lituanica, Nr. 3(19), 1994, 77-97.

5 J. Bagušauskas. Prienų Lietuvos jaunimo sajunga 'Jaunoji Lietuva'. Lietuvos archyvai, t. 6, 1995, 3-15.

${ }^{6}$ Nijole Gaškaitè. Jaunimo pasipriešinimas ir jo slopinimas šeštajameseptintajame dešimtmetyje. Laisvés kovu archyvas, t. 19, 1996, 5-52, ff.

7 J. Bagušauskas. R. Kalanta ir jaunimo pasipriešinimas. Lietuvos gyventoju genocido ir resistencijos tyrimo instituto darbai. Nr. 2, 1996, 105-116.

${ }^{8}$ Kęstutis Lakickas. Kalinys Z-311. Atsiminimai. Vilnius: Mokslo ir enciklopediju leidykla, 1994; Studentu byla. Vilnius: Diemetis, 1995; Alma Mater auklètiniai kovos sajūdyje. Laisvés kovu archyvas, t. 18, 1996, 111-130; Palangos gimnazijos 1945-1948 m. pogrindis ir pogrindininkų likimai (2) Comp. by Vytautas Rimgaila. Laisvès kovu archyvas, t. 21, 1997, 119-137, ff. 
interpretation of sociologists, we consider all people up to the age of 29 as 'youth' - young town and rural workers, young intelligentsia and civil servants. This concept also comprises students of secondary schools and institutes of higher education as well as those organizations, which the Communist Party and repressive structures characterized as 'youth groups' or 'organizations'. The partisan movement, the participants of which also consisted mainly of young people, is dealt with only in as much as it was associated with the formation of youth organizations. That specific active armed resistance to the regime is an object of a special research.

The destruction of Lithuanian statehood after the occupation and annexation of the country in 1940 and the Sovietization of social and political life provoked resistance which grew proportionately to the scale of political repression, economic expropriation and the deterioration of standards of living. Resistance, starting with the turning of one's back on Soviet political actions and the creation of anti-Soviet folklore, developed into organized resistance, which the Lithuanian Activist Front, set up in the autumn of 1940, attempted to unite. Numerous groups and circles sprang up under the influence of the LAF, consisting of students, leaders and rank and file members of organizations closed by the Soviets. Many circles functioned in secondary schools. Due to their young age their members could not be included in the LAF, nevertheless, they were very active. 'They were young idealists, sometimes children of victimized parents'. ${ }^{9}$ Secret organizations and underground publications fostered the freedom aspirations of the people and the hostile attitude of youth towards the Soviet regime. Pupils, who at the start of the academic year were favourably disposed toward the Soviet power and the Komsomol, or at least loyal to them, began acting against them. ${ }^{10}$ Soviet archival sources indicate that between July 1940 and May 1941 the NKVD uncovered 75 various illegal organizations and groups, to which 36,000 members $^{11}$ belonged, many of them young people.

${ }^{9}$ Jonas Petras Kedys. Terorizuojama ir naikinama Lietuva. 1938-1991. Klaipeda, 1994, 114-115.

${ }^{10}$ LTSR Švietimo Liaudies Komisariato inspektoriaus 1940 m. lapkričio mèn. raštas Vidaus reikalų komisarui (Report from an inspector of the LSSR People's Commissariat for Education to the Internal Affairs Commissar, Nov. 1940). LCVA, f. R-762, ap., 6, b. 47, 1. 184.

${ }^{11}$ A. Vitkovskii, V. Iampolskii. Eto bylo vchera. Dokumenty o litovskikh sobytiiakh 40-50-kh godov. Izvestiia TCK KPSS, no. 10, 1990, 134. 
The majority of Lithuanians never doubted that freedom would be recovered and that feeling was not lost. The Lithuanian people longed to be free from the very first days of the occupation. 'As all people have the right to freedom, so all nations have the right to live freely', ${ }^{12}$ wrote Juozas Girnius. The May 1941 programme drawn up by the Lithuanian Activist Front stated that 'the Lithuanian nation believes in its independent statehood as the guarantee of national self-expression and the most perfect organizational form. Humanity so far has not yet found a better way of national organization and fruitful life than the independent state. ${ }^{13}$ The most important issue in discussions of the restoration of statehood and the country's freedom was the obliteration of occupation - it was constantly stressed that any available means were justified, acceptable and worth using in the elimination of the Bolshevik occupation. ${ }^{14}$ The political objectives of resistance encouraged the formation of secret youth organizations, which proclaimed the re-establishment of independent Lithuania as their primary aim.

Having originated in the first years of Soviet and German occupations, the resistance movement continued its struggle for independence in the period of the second Soviet occupation. Parallel with partisan units, secret youth organizations were set up, often initiated by the partisans, urging young people to join the fighters for the freedom of Lithuania. ${ }^{15}$ The members of the youth organizations were active supporters of the partisans and made up their reserve units. Nearly a half of the partisan proclamations were distributed by secondary school students. ${ }^{16}$ The partisans would send young people to various Soviet institutions in order to obtain necessary information. On the initiative of partisan district headquarters many so called 'Organizational Sector groups' of the Lithuanian Freedom Army (Lietuvos Laisvès Armija; hereafter referred to as the OS of the LLA) were set up. Many young people, in particular secondary school pupils, were their members. These groups also included

12 Juozas Girnius. Tauta ir tautine ištikimybe. Chicago, Ill., 1961, 59.

${ }^{13}$ Kazys Škirpa. Pastangos gelbèti Lietuvą. Priedai prie atsiminimų. LVOA, f. 3377 , ap. 48, b. 712 , 1. 112-113.

${ }^{14}$ Ibid., p. 111.

${ }^{15}$ Pažymint Lapkričio 23. Laisvès varpas. Jungtinès Kęstučio apygardos organas. 1948.

${ }^{16}$ N. Gaškaitè. Pasipriešinimo istorija. 1944-1953 metai. Vilnius: Aidai, 1997, 97. 
partisans, who had legalized themselves, and those who were ready, should the necessity arise, to join the ranks of the freedom fighters. Although in 1948-1949 the NKVD managed to uncover and liquidate many OS and partisan reserve groups, resistance activity was not completely destroyed. Further assistance was offered to the partisan movement and new student organizations came into existence. A report of the MGB indicated to the Secretary of the Central Committee of the LKP(b) that 'bandit and nationalist formations, exploiting members of kulak families, bandits and those repressed by Soviet administrative organs, conduct anti-Soviet nationalist propaganda, disseminate antiSoviet literature and are engaged in surveillance and material support activity for the bandits'. ${ }^{17}$ A partisan newspaper wrote in 1950 that the partisans did much to instil a spirit of courage and self-sacrifice in the hearts of young people. ${ }^{18}$ In K. K. Girnius' words, 'There are indications that sometimes all the children of a particular form in the school were associated with the underground movement in one way or another' ${ }^{19}$ In addition to the structures established on the initiative of the partisans, young people themselves independently set up clandestine political organizations. Their members were mostly students and young intellectuals. Throughout the entire period of the Soviet regime approximately 450 youth organizations, uniting about 3,500 young men and women, were uncovered. The following table shows the numbers of the organizations and their members between 1940 and 1988.

\begin{tabular}{|l|c|c|}
\hline \multicolumn{1}{|c|}{ Year } & \multicolumn{2}{|c|}{ Number } \\
\hline & of organizations & of members \\
\hline $1940-1941$ & 34 & $89^{*}$ \\
1945 & 38 & 397 \\
1946 & 18 & 198 \\
1947 & 20 & 132 \\
1948 & 18 & 186 \\
1949 & 25 & 294 \\
1950 & 28 & 238 \\
\hline
\end{tabular}

${ }^{17}$ LTSR MGB $1949 \mathrm{~m}$. birželio pranešimas LKP(b) CK apie tautinio pogrindžio ittaką jaunimui (Report of the LSSR MGB to the Central Committee of the LCP(b), June 1949, on the influence of the nationalist underground on the youth). LYA, f. K-1, ap. 10, b. 75, 1. 285.

${ }^{18}$ Partizanai. Malda girioje. LLKS. Žemaičių apygardos visuomeninès minties organas. Lietuvos istorijos instituto rankraštynas (Social thought organ of the Žemaitija District. MS. in Lithuanian Institute of History).

${ }^{19}$ K. K. Girnius. Partizanu kovos Lietuvoje. Vilnius: Mokslas, 1990, 116. 
Cont.

\begin{tabular}{|l|c|c|}
\hline & of organizations & of members \\
\hline 1951 & 44 & 304 \\
1952 & 18 & 116 \\
1953 & 6 & $14 *$ \\
1954 & 20 & 234 \\
1955 & 20 & 147 \\
1956 & 18 & 111 \\
1957 & 31 & 156 \\
1958 & 10 & 47 \\
1959 & 16 & 101 \\
1960 & 15 & 103 \\
1961 & 5 & 138 \\
1962 & 1 & 3 \\
1964 & 7 & 28 \\
1967 & 2 & 13 \\
1968 & 13 & 71 \\
1969 & 7 & 46 \\
1970 & 11 & 72 \\
1971 & 7 & 38 \\
1972 & 2 & 21 \\
1973 & 3 & 7 \\
1974 & 6 & $\ldots$ \\
1975 & $\ldots$ & 87 \\
1977 & 5 & 32 \\
1982 & 1 & $\ldots$ \\
1988 & 1 & 3 \\
& 450 & 3426 \\
\hline
\end{tabular}

*Inaccurate data

... No data available.

The names of organizations usually repeated the ones of those, which had functioned in independent Lithuania and reflected the principal aims of the youth. The members of the organization, called 'Laisvę Lietuvai' (Freedom for Lithuania), wrote in their programme that their organization's objective was expressed in its name. ${ }^{20}$ In their names the organizations endeavoured to express their opposition to the regime. A youth organization, uncovered by the KGB in the Jurbarkas district on 26 August 1958, called itself 'Antikomunistinè lietuvių kovotojų sajunga' (Anti-Communist Union of Lithuanian Fighters). Its main aim was to fight against the Communists. ${ }^{21}$ Many youth organizations had similar names and objectives.

${ }^{20}$ Aleksandro Krasausko ir kt. baudžiamosios bylos 1958060605 kaltinamoji išvada (Legal case against A. Krasauskas et al., June 5, 1958). LYA, b. $44614 / 3$, t. $6,1.276$.

${ }^{21}$ LTSR KGB 19570912 specialus pranešimas. (Special report of the LSSR KGB, Sept. 12, 1957) LYA, f. K-1, ap. 3, b. 483, 1. 195. 
What motives had young people in joining such organizations? The ideas of re-establishing Lithuanian statehood and resisting the regime were cherished by young people in the face of political violence and the unwillingness and inability of the Soviet authorities to tackle questions of everyday life. In their conversations young people took a critical attitude toward events of the Soviet political and economic life, the regime's policies, the primitive nature of Soviet technology, etc. Such meetings of like-minded young people led to the appearance of organizations. The youth was aware that Socialism was not a system which could ensure society a normal economic life. Interrogated by the KGB, Janina Vanagaite stated on 3 October 1959 that Socialism in Lithuania could not offer her material assistance; her mother and sister helped her more. ${ }^{22}$ Rapidly evolving youth organizations considered the Communist Party and its members to be the cause of all the evils in national life.

Opposition to the policy of Russification and to the disparagement of national sentiment was one of the main reasons behind the rise and activity of underground organizations. In the documents of these organizations demands were made constantly to promote national harmony and to mobilize support for the creation of cultural values, "which are the highest fulfilment of human endeavours and a remarkable manifestation of national identity'. ${ }^{23}$ 'The point is that we can fill our bellies and get rich being citizens of any state. In principle we can acquire personal freedom and social justice. Nevertheless, we still consider it our duty to save our language and culture from the threat of disappearance'. ${ }^{24}$ These issues became particularly evident in the period known as the 'Khrushchev Thaw'. Criticisms were often voiced against the Russians not as human beings, but as representatives of a regime, oppressing other nations. Under KGB interrogation, the leader of the 'Underground Youth Organization of 16 February', functioning in the 16th training college of Kaunas, Vytautas Gražulis stated: 'The main reason for the formation of the organization was the fact that 90 per cent of the student body are Lithuanian and only 10 per cent are Russians. However, only the Russian language is used in the

22 J. Vanagaitès 19591003 pareiškimo 19591004 tęsinys (Continuation of J. Vanagaitè's account, Oct. 3, 1959). LYA, f. K-1, ap. 3, b. 519, 1. 133.

${ }^{23}$ K. Škirpa. Pastangos gelbèti Lietuvą, 1. 122.

${ }^{24}$ A. Langemestas. Apie nacionalizmą, kultūrą ir tautos kultūrą. Metai. no. $9,1991,120$. 
school. That situation has been causing great discontent among the students'. ${ }^{25}$ Young people were angered by the unwillingness of the newcomers to learn Lithuanian and their demand that the local people speak Russian to them, thus treating the Lithuanians as second-rate citizens.

Young people were also irritated by the attempts of the regime to send Lithuanians to work in various regions of the Soviet Union after graduation. In appointing specialists to posts in Lithuanians enterprises, headed by the newcomers, Lithuanian youth was ignored, and that made the policy of Russification still more evident. This phenomenon assumed such proportions that even the KGB had to pay attention to it. 'In addition, some enterprise and department managers are prone to view young specialists of Lithuanian descent critically, thus creating an atmosphere of distrust and placing various obstacles in the way of their promotion. Obstacles of that kind beget discontent not only among young specialists, but also among students in institutes of higher and secondary vocational education ... Taken all in all, these circumstances aggravate the political situation in the republic, cause discontent among the working people and create conditions for the existence of the relics of nationalist and bourgeois ideology, enabling the activity of hostile elements' ${ }^{26}$ At first glance, such insignificant, everyday events, which the authorities often referred to as trivial, also reflect the Soviet policy of destroying local national identity, which caused the youth to protest.

Many organizations linked the realization of their objectives with the general struggle of all nations for their freedom. Such was the idea behind the struggle of the 'Laisva Lietuva' (Free Lithuania) organization. In its documents, it stated that in order to re-establish statehood it was necessary in the first place to actualize the national issue. Simultaneously hatred towards the occupiers will be instigated. The rising wave of resistance will recruit new fighters. In their programme they also maintained that 'on our way we must not be blind nationalists. All nations have the right to self-determination. We must support Africa, we must also support some Soviet initiatives (in the sphere

${ }^{25}$ LTSR KGB 19560429 informacija (Information from the LSSR KGB, Apr. 29, 1956). LYA, f. K-1, ap. 3, b. 468, 1. 108-111.

${ }^{26}$ LTSR KGB ataskaita apie darbą 1958 metais (Annual Report of the LSSR KGB, 1958). LYA, f. K-1, ap., 10, b. 253, 1. 248-249. 
of education, medicine), but, we must always be enemies of racial hatred and Russification'.27

Concealing and falsifying Lithuania's past encouraged young people to look for answers to historical problems by themselves. Frequently one of the aims of youth organizations was the study of Lithuanian history as an important aspect in the preparation for their struggle for freedom. In order to understand better ongoing political processes the members of underground organizations looked for the national experience of the past, collected books on history, published in independent Lithuania and set up clandestine libraries.

The establishment of youth resistance organizations was activated not only by the political situation inside the country, but also by foreign radio broadcasts in Lithuanian and the hostile attitude of parents towards the Soviet regime. The 4 January 1956 report of the Fourth department of the KGB, dealing with the influence of nationalist centres, stated that 'backward intelligentsia and youth are still greatly influenced by Lithuanian nationalist centres abroad, which, using the radio stations of capitalist countries, slander the Soviet state, distort the measures taken by the Soviet authorities in strengthening the system of collective farms in Lithuania and incite the nationalists residing in Lithuania to active propaganda'. ${ }^{28}$

In the 1950s the nature of youth resistance modified as a consequence of historical changes. A new tactic - 'organization without organization' - developed in order to save the members. When the KGB detected an underground organization, all the members were persecuted and repressed. Meanwhile, arrests of individual members could not influence the activity of the entire organization very much. Other members, being free, could continue the work. A member of the youth organization 'Jaunoji Lietuva' (Young Lithuania), which functioned in Prienai in 1951, Vytautas Podriezas spoke after his release from prison: 'We must also be ready. Those who remained faithful must be rallied closely and in case of necessity must know the situation and the way they must act. I am not saying that we must be organized into

${ }^{27}$ Organizacijos 'Laisva Lietuva' programa (Agenda of 'Laisva Lietuva'). LYA, f. K-1, ap. 3, b. 36, 1. 73-74.

${ }^{28}$ LTSR KGB 4 valdybos 19560104 pažyma dèl tautinių centrų įtakos atskiroms inteligentijos ir jaunimo grupems (Note by head of the LSSR KGB on Jan. 4, 1956 concerning the influence of nationalist centres on diverse youth and intellectual groups). LYA, f. K-1, ap. 3, b. 471, 1. 39. 
fully documented groups as previously. That would be a suicide. We must learn from the mistakes of the past.... There is no need to establish contacts with many people and to recruit them. It is sufficient to have 80 reliable people in the region of Kaunas from the 8,000 , who have returned from prisons, so that in case of necessity we could occupy the strategic objects within the city ....' ${ }^{29}$

After Stalin's death young intellectuals took advantage of the political 'thaw' by establishing clubs for open discussion of matters of current topical interest. In 1955 a group of students at the Vilnius Institute of Art studied theoretical questions of art and were critical of socialist realism, raised the issues of Lithuania's freedom and came out against the occupation and Russification of the country. Students used to read memoirs, published in independent Lithuania and abroad, books by Bernardas Brazdžionis and other authors and preferred to write graduation works on topics related to the history of Lithuania. ${ }^{30}$ Young intellectuals urged the Writers' Union to pay greater attention to the nation's cultural heritage by publishing the works of Maironis and other classics of Lithuanian literature. They also demanded a return to the old names of streets, which had been renamed in the Soviet manner, etc. This interest in national heritage, which fostered patriotic sentiment, was not approved by the Communist Party and Komsomol structures. These groups which functioned legally were closed, and their members B. Baliulevičius, A. Tarabilda and V. Kisarauskas (students of the Institute of Art) were accused of disseminating 'nationalist bourgeois ideas'.

Students of literature started ignoring the enforced Soviet dogmas; this tendency was particularly evident in the University of Vilnius. KGB reports speak about the literary circle which functioned at the Department of Lithuanian Literature. Those students were interested in the Lithuanian literary heritage, and in the works of 'the writers, who had made ideological mistakes', and they 'idealized them'. The organizers of 'the decadent group'

${ }^{29}$ LTSR KGB pirmininko Alfonso Randakevičiaus pranešimas vadovaujančių darbuotojų 1961 vasario mèn. pasitarime (Report of the Chairman of the LSSR KGB A. Randakevičius in the Feb. 1961 managers' conference). LYA, f. 4421, ap. 14, b. 16, 1. 27-28.

${ }^{30}$ LTSR KGB 195801 06-07 specialus pranešimas TSRS KGB (Special report of the LSSR KGB to the USSR KGB, Jan. 6-7, 1958). LVOA, f. 4421, ap. 14 , b. $16,1.27-28$. 
were students Tomas Venclova, Juozas Tumelis and Pranas Jackevičius. According to the KGB, their entourage was 'elements, participating in decadent literary work and politically unstable'. In 1956 attempts were made on the initiative of Valentinas Ardžiūnas to publish a historical newspaper at the University. ${ }^{31}$ Repression was carried out against the patriotically minded young scholars at the Institute of History and other research institutions.

The 'organization without organization' campaign intensified after the Brezhnevite suppression into Czechoslovak Spring, leading to the rise of the dissident movement. In 1968 the KGB stated that being indoctrinated by foreign propaganda and nationalist elements, intellectuals, students and pupils sometimes refuse to recognize the Party's influence in creative work, and that inertia is detectable in political life. Young people are engaged in dangerous discussions of national issues, questions of personal freedom, and the standard of living in the USSR, and scepticism and nihilism are not alien to them. On the grounds of such an attitude some young people commit politically harmful acts, even attempting to set up anti-Soviet and ideologically destructive groups. The conclusion is drawn that organized actions against the Soviet authorities are possible, and the need to strengthen the positions of the KGB not only within Lithuania, but also outside the USSR is stressed..$^{32}$

The appearance of Lietuvos Kataliku Bažnyčios Kronika (Chronicle of the Lithuanian Catholic Church) on 19 March 1972, the formation of a new underground press, the documents of the Helsinki Accords of 1975, outlining the respect for human rights, - all these events were significant in strengthening young people's aspirations of freedom. The principal characteristic of the resistance movement became the requirement for the government of the USSR to adhere to constitutional provisions and laws, regulating the rights and freedoms of the citizens. Young people set up their own organizations in support of the Helsinki movement. On 15 June 1977 a statement was published in the West, requiring the withdrawal of the Soviet Army from the Baltic states, the calling of a referendum on the future of these states

${ }^{31}$ LTSR KGB 19570524 specialus pranešimas (Special report of the LSSR KGB, May 24, 1957). LYA, f. K-1, ap. 3, b. 483, 1. 140-141.

${ }^{32}$ LTSR KGB agentūrinio, operatyvinio ir tardymo darbo 1968 metais ataskaita (Annual report on the work of KGB agents, operatives and interrogators in the LSSR, 1968). LYA, f. K-1, ap. 10, b. 372, 1. 3-4. 
and the punishment of KGB and other Soviet officials, guilty of crimes against the nation and humanity. The signing of the final documents of the Helsinki Conference in 1975 added new aspects to the resistance movement and enabled the creation of new trends which differed in their political orientation. A variety of movements and trends shows that in Soviet society there remained not a single person, neither a sincere Marxist nor a Communist, who could believe in the slightest degree in the regime, which then controlled the Soviet Union,' wrote Aleksandras Štromas, characterizing the political situation in Lithuania in the $70 \mathrm{~s}^{33}$

\section{Principles of the Organization of Youth Resistance}

Youth resistance organizations conducted their activity according to prepared and approved statutes. The files of lawsuits brought against the members of resistance organizations contain the original statutes or Russian translations or simply oral versions of them, which reflect the aims and organizational principles. In addition to the main spheres of activity, the statutes also set down membership requirements. Thus, the statute of 'Lietuvos laisves varpas' (the Bell of Lithuanian Liberty) indicates that the organization unites directly or indirectly pupils and students in the struggle against the occupiers of the motherland. ${ }^{34}$ 'Lietuvos Laisvès Armija' (Lithuanian Freedom Army) did not accept members of the Komsomol and did not allow its members to enter the Komsomol, treating it as a nationally alien organization. 'Only well-known and physically strong men'35 could be admitted to the organization. Attitudes to the Komsomol varied. The organization 'Laisvès švyturys' (Freedom Beacon), which functioned in Kaunas between 1948 and 1950, decided in its meeting in October 1949 that the members of the organization could join the Komsomol. Entering that Soviet organization was a conscious act to camouflage the activity of one's own secret organization. Any young Lithuanian, wishing to fight for

${ }^{33}$ Aleksandras Štromas. Opozicija Tarybų Lietuvoje Sëja, no. 2, 1977, 112.

${ }^{34}$ LTSR MGB 19521129 pranešimas LKP(b) CK apie organizacijos "Lietuvos laisvés varpas" atskleidimą (LSSR MGB Report to the Central Committee of the LCP(b) on the uncovering of 'Lietuvos laisvès varpas', Nov. 29, 1952). LYA, f. K-1, ap. 10, b. 145, 1. 150.

${ }_{35}$ Albino Kurtinaičio 19540421 parodymai apie veiklą $195307-1954$ 0421 (A. Kurtinaitis' evidence (Apr. 21, 1954) concerning events of July 1953 -Apr. 21, 1954). LYA, b. 31964, 1. 27, 30. 
Lithuania's independence, could be a member of 'Lietuvos jaunimo sajunga' (Lithuanian Youth Union), which operated in Raseiniai in $1956 .{ }^{36}$ The regulations of the student organization 'Lietuvos laisvès gyneju sajunga' (Union of the Defenders' of Lithuania's Freedom) stated that any honest Lithuanian Catholic could be its member. ${ }^{37}$ Some organizations accepted only educated young people. The statute of 'Vieningoji darbo sajunga' (United Labour Union) stated that its members had to accept the association's agenda, be able to analyze the social systems of various states and to broaden their education. ${ }^{38}$ Applicants had to write an essay or article analyzing the domestic and foreign policy of the USSR or any other political problems of the country or the world. ${ }^{39}$ The age of future members was also indicated in the statutes. According to the statute of 'Kova už laisvę' (Struggle for Freedom), its members could not be younger than 17 years old. ${ }^{40}$ The members of 'Laisva Lietuva' had to be at least 18 years old, and only in exceptional cases, could 17-year-olds be admitted. ${ }^{41}$ The majority of these organizations did not limit the age of their members in any way, since practically all of them were of the same age.

Resistance organizations included young people of various social strata in their ranks. The publication Malda girioje (Prayer in the Forest) stated that the freedom fighters of those heroic units were 'the sons of grey Lithuanian fields and daughters of fine linen weavers' ${ }^{42}$ Some idea about the social composition of the organizations can be obtained from data, compiled by the KGB. Between 1956 and 195731 youth organizations were uncovered and dissolved. They comprised 159 persons. Among them there were 56 pupils of the lower forms (up to the seventh

${ }^{36}$ LTSR KGB 19560919 informacija (LSSR KGB information, Sept. 19, 1956). LYA, f. K-1, ap. 3, b. 468, 1. 151-154.

${ }^{37}$ LTSR KGB 19571129 informacija (LSSR KGB information, Nov. 29, 1957). LYA, f. K-1, ap. 3, b. 483, 1. 299.

${ }^{38}$ LTSR MGB 19520620 pranešimas TSRS MGB (LSSR MGB report to MGB of USSR, June 20, 1956). LYA, f. K-1, ap. 10, b. 141, 1. 139.

${ }^{39}$ LTSR MGB 19520321 pranešimas TSRS MGB (LSSR MGB report to MGB of USSR, March 21, 1952). LYA, f. K-1, ap. 10, b. 93, 1. 82.

40 'Kovos už laisvę' organizacijos statutas (Statute of 'Kova už laisvę'). LYA, f. K-1, ap. 10, b. 4, 1. 268.

${ }^{41}$ Jaunimo organizacijos 'Laisva Lietuva' programos vertimas (Translation of the agenda of 'Laisva Lietuva'). LYA, f. K-1, ap. 3, b. 36, 1. 75.

${ }^{42}$ Lietuviškai inteligentijai. Malda girioje, no. 2, gruodžio 22 1949, 24. 
form), 61 pupils of the higher forms of the secondary and vocational schools, 24 students of the institutions of higher learning, 18 young members of collective farms and workers. Among them there were 54 children of workers, 59 of collective farmers, 29 of civil servants and 4 of big landowners. In the first post-war years the village youth mostly became members of partisan units and those of underground organizations were pupils and students, whereas in the "50s young workers and collective farmers became involved increasingly in the activity of resistance organizations. That could have been a result of the suppression of the partisan movement and obligatory job assignments in factories and collective farms for the school leavers. The social structure of resistance members shows that the struggle in the first place was directed against the Soviet regime, and not because of 'lost wealth', as was claimed in the official press and in Communist Party documents.

When they entered an organization, young people had to take an oath, in which the principal aims and objectives of the particular organization were stated. In the first post-war years the texts of partisan oaths were used for the most part. Occasionally the organizations themselves created their own oaths, reflecting the main objectives of the struggle for freedom. In March 1950 a Vilnius organization 'Aušros Vartų Marijos vaikai' (Children of the Mary of the Aušra Gate) was uncovered. Its members had sworn an oath not to take part in any entertainment as long as the national mourning and sorrow lasted, until the deportees, prisoners and émigrés returned; the partisans could not be happy until they saw the nation's wounds healed. They undertook to honour those fallen for the nation's freedom, to look after their graves, to support the freedom fighters as far as possible and to maintain ties with their relatives. ${ }^{43}$ The members of 'Laisvę Lietuvai' (Freedom for Lithuania), which functioned in 1956-57, took an oath on behalf of the nation to fight for Lithuania's freedom. The oaths were uncompromising, requiring discipline and unconditional selfdenial. A member of the organization 'Geležinis vilkas' (Iron Wolf), established in Kaunas in 1955, Algirdas Liorentas composed an oath, which stated: 'On entering the organization I pledge to fight for the independence of Lithuania. I pledge not

${ }^{43}$ LTSR MGB 1950059 specialus pranešimas TSRS MGB (Special report of the LSSR MGB to the USSR MGB, May 9, 1950). LYA, f. K-1, ap. 10 , b. $94,1.240$. 
to betray the secret of the organization and to fight for the independence of Lithuania till the end of my life'. ${ }^{44}$ According to circumstances oaths could be solemn, with the performance of various rituals, including signing in blood. All the members had to make a statement about their free decision to participate in the struggle for Lithuania's freedom. One's belonging to the organization was attested both by the oath and a membership card. Many organizations did not issue any cards for this was not in keeping with their clandestine mission.

In order not to be trapped by the $\mathrm{KGB}$, organizations looked for cover. In 1944-45 the 'Ateitininkai' (a Catholic youth organization) functioned in the secondary school in Utena under the cover of a philosophy group. A student of the Pedagogical Institute of Vilnius A. Masaitis established an underground organization as a Lithuanian history study group. ${ }^{45}$ The members of the organizations also used noms de guerre or even numbers. The need for concealment also conditioned the organization structure. Larger organizations were split into smaller units of three or five members. For the same purposes some organizations limited the number of their members in order to avoid admitting unreliable members. ${ }^{46}$

Questions of leadership were also discussed in the documents of the resistance organizations. Some organizations made decisions not to elect any leaders and to solve all matters collectively. ${ }^{47}$ There were organizations, which were managed by all members in rotation. In 'Vieninga darbo sajunga' routine matters were settled by the chairman and a group of secretaries. ${ }^{48}$ Conferences were convened for the discussion of issues relating to the activities of the organization.

${ }^{44}$ Algirdo Mickevčiaus 19560221 tardymo protokolas (Interrogation record of A. Mickevičius, Feb. 2, 1956). LYA, b. 39023/3, t. 2, 1. 74-75.

${ }^{45}$ LTSR KGB 19561129 specialus pranešimas LKP(b) CK (LSSR KGB special report to the Central Committee of the LCP(b), Nov. 29, 1956). LYA, f. K-1, ap. 3, b. 468, 1. 194.

${ }^{46}$ LTSR MGB 19521016 pranešimas LKP(b) CK (LSSR MGB report to the Central Committee of the LCP(b), Oct. 16, 1952). LYA, f. K-1, ap. 10, b. $145,1.92$.

${ }^{47}$ A. Liorento 19560218 tardymo protokolas (Interrogation record of A. Liorentas, Feb. 18, 1956). LYA, b. 39023/3, t. 1, 1. 98.

${ }^{48}$ LTSR MGB 19520620 pranešimas TSRS MGB (LSSR MGB report to USSR MGB, June 20, 1952. LYA, f. K-1, ap. 10, b. 141, 1. 139. 
Trends in the Activities of Youth Resistance Organizations

The practical activity of a vast majority of organizations was directed toward the patriotic education of their members and of young people in general. Under the conditions of occupation the printed word was the most acceptable form for that work. The first underground publications appeared during the first Soviet occupation, and they enunciated the ideas of Lithuanian freedom and statehood and informed the public at large about what was going on in the world. On 30 December 1951 the meeting of the organization 'Laisvès varpas' stated that 'at present there is no force for an armed resistance in our country, therefore, we, members of the organization, shall fight against Soviet rule in Lithuania by attracting the masses to our side, and that can be done with the help of the printed word, i.e., writing and disseminating various proclamations, sending anonymous letters'. ${ }^{49}$

In the first post-war years the publication of youth underground literature was closely connected with newspapers issued by the partisans. Young underground activists prepared articles for publication and distributed printed materials. Youth organizations also published their own newspapers expressing their reaction to the urgent everyday issues. 'Slaptas Vilties Ratelis' (Secret Circle of Hope) issued a newspaper Žaibas (Lightning) $)^{50}$ in 1945, the 'Ateitininkai' - Pavergtos Lietuvos vaduotojas (Liberator of Oppressed Lithuania) ${ }^{51}$, a group of pupils from Tauragè - Lietuvos balsas (Voice of Lithuania) ${ }^{52}$, 'Lietuvos Jaunimo Vyčiu Sajunga' (Union of Knights of Lithuanian Youth) - Laisves keliu (On the Freedom Road) ${ }^{53}$ and in 1955 the organization of the Ignalina secondary school "

${ }^{49}$ LTSR MGB 1952 m. pranešimas TSRS MGB (papildymas prie 1952 02 26) (LSSR MGB report to USSR MGB, 1962; Supplement to report of Feb. 26, 1952). LYA, f. K-1, ap. 10, b. 93, 1. 74-75.

${ }^{50}$ Vytauto Puteikio 19460212 tardymo protokolas (Interrogation record of V. Puteikis, Feb. 12, 1946). LYA, f. K-1, ap. 8, b. 2, 1. 54.

${ }^{51}$ NKGB ir NKVD 19510911 paaiškinamasis raštas (Explanatory text from NKGB and NKVD, Sept. 11, 1951). LYA, f. K-1, ap. 18, b. 2, 1. 215.

${ }^{52}$ LTSR MGB 19511008 pranešimas TSRS MGB apie LTSR 5 skyriaus agentūrinị ir operatyvinį darbą 1951 07-08 (LSSR MGB report to USSR MGB, Oct. 8 1951, concerning the work of agents and operatives of Section 5, JulyAug., 1951). LYA, f. K-1, ap. 10, b. 129, 1. 7-8.

53 Algimanto Urbšto 19510428 tardymo protokolas (Interrogation report of A. Urbštas, Apr. 28, 1951). LYA, b. P-16416-Li, t. 1, 1. 25. 
Jaunieji keršytojai' (Young Avengers) issued the newspaper Aušra (Dawn). ${ }^{54}$ These publications and their distribution sometimes were the reasons for the creation of the organization itself.

The period of the political 'thaw' was accompanied by some attempts to publish works legally. In 1958 the students of literature of the University of Vilnius prepared an almanac of their works for publication. The appearance of Lietuvos Kataliku Bažnyčios Kronika and processes, related to its publication, encouraged the arrival of new periodicals. In the course of several years the Lithuanian underground press developed into a strong political force in the struggle for human and national rights and freedoms.

The preparation and distribution of proclamations was the most widespread form of the activity of youth organizations. These publications responded to the political actions of the Soviet regime, urged the population to ignore the measures, supporting the regime, to boycott obligatory grain deliveries, to condemn the occupation and the Russification policy, as well as other Soviet initiatives. The proclamations also contained information about the main events in world politics and reminded their readers of significant events in the history of the nation. In the opinion of the Kaunas organization 'Laisvès švyturys', such proclamations should incite the discontent of the population with the regime and prepare the struggle against it. ${ }^{55}$ The youth was encouraged to unite into organizations. ${ }^{56}$

The distribution of leaflets acquired great proportions. According to the KGB data, on 1 October 1955 a search was conducted for the authors of 363 proclamations and 416 anonymous letters ${ }^{57}$ and in 1956 as many as 117 distributors of such resistance materials were discovered. Among them there were 30 teenagers younger than 16 years old, and 25 young people

${ }^{54}$ LTSR KGB 19550820 pranešimas (LSSR KGB report, Aug. 20, 1955). LYA, f. K-1, ap. 3, b. 451, 1. 42.

${ }^{55}$ Henriko Jankausko 19500408 tardymo protokolas (Interrogation record of H. Jankauskas, Apr. 8, 1950). LYA, b. P-17620-Li, 1. 65.

${ }^{56}$ Atsišaukimas "Kreipimasis ị Pasvalio moksleivius" ("Call to the school children of Pasvalys'). LYA, f. K-1, ap. 8, b. 2, 1. 80.

${ }^{57}$ LTSR KGB 19551105 pažyma apie TSRS KGB 19541206 ịsakymo Nr. 00799 vykdymo 4 valdyboje patikrinimą (LSSR KGB note (Nov. 5, 1958) on the implementation of USSR KGB Instruction No. 00799 (Dec. 6, 1954) in Section Four). LYA, f. K-1, ap. 3, b. 471, 1. 73-74. 
between 16 and 25 years. ${ }^{58}$ In 1957 the number of such distributors was 182; they delivered 633 copies of proclamations and 342 anonymous letters. ${ }^{59}$ According to the data, collected by the repressive organs in Lithuania in 1960, proclamations and letters were distributed 43 times ${ }^{60}$ in 1961 - 22 times, in 1962-63 -26. ${ }^{61}$ The distribution of great numbers of leaflets in many localities in 1967 angered the KGB. In order to determine the authors of the proclamations, the KGB resorted to the services of loyal philologists, psychologists and psychiatrists. Their conclusions were used in establishing the authors of illegal literature. ${ }^{62}$ In it appeals were often made to writers and artists. Therefore agents from the corresponding spheres were brought in action. Specimens of typewriter characters were collected in all offices and enterprises. Agents and other reliable persons were used to get character specimens of privately owned typewriters. The search for such typewriters was carried out by examining the archives of offices and organizations, which received many personal documents from the general population. When suspicion arose that the author and distributor of particular proclamations could be a person from Viduklè, 200 people of that origin were found throughout Lithuania. Special personal files were kept and each suspect was screened accordingly. ${ }^{63}$

Most proclamations were issued on the occasion of February 16 and they were specially designed for that date Lithuanian declaration of independence in 1918.

${ }^{58}$ LTSR KGB 1957 birželio mèn. specialus pranešimas TSRS KGB (Special report of LSSR KGB to USSR KGB, June, 1957). LYA, f. 8, ap. 17, b. $1,1.147$.

${ }^{59}$ LTSR KGB 19580302 informacija (LSSR KGB information, Mar. 2, 1958). LYA, f. K-1, ap. 3, b. 502, 1. 32.

${ }^{60}$ LTSR KGB pirmininko Alfonso Randakevičiaus pranešimas vadovaujančių darbuotojų $1961 \mathrm{~m}$. vasario mèn. pasitarime (Chaiman of the LSSR KGB A. Randakevičius' report at the conference of the managers, Feb. 1961). LYA, f. K-1, ap. 10, b. 301, 1. 44.

${ }^{61}$ LTSR KGB 19630620 pažyma apie agentūrinị bei operatyvinị tardymo darbą (LSSR KGB note on the work of agents, operatives and interrogators, June 20, 1963). LYA, f. K-1, ap. 10, b. 324, 1. 169.

${ }^{62}$ LTSR KGB tardymo skyriaus veikla. $1972 \mathrm{~m}$. (Work of Interrogation Department of LSSR KGB, 1972). LYA, f. K-1, ap. 10, b. 405, 1. 139.

${ }^{63}$ LTSR KGB 19760511 pažyma apie baudžiamąją bylą Nr. 251 (LSSR KGB commentary on case no. 251, May 11, 1976). LYA, f, K-1, ap. 10, b. 438, 1. 143 . 
Underground organizations expressed their attitude toward the regime not only by the proclamations, but also by publicizing the slogans, insignia and symbols of the Lithuanian state. That was the practice of denouncing the regime and of reminding the people of the times of independence and of important dates in the national history. Some of those appeals contained an urge to drive the occupiers out of the country and others called for the fight against the supporters of the Communist regime.

One more form of youth resistance was writing letters to various Soviet institutions. Letters, criticising the Soviet system and exposing the policy of national subjugation, were sent to the Communist Party offices. On 29 December 1972, 72 letters were sent from various Vilnius post offices to different town and district institutions in Kaunas, Šiauliai, Kapsukas and other places; twelve letters were addressed to the agitation and propaganda departments of urban and district Party committees, sixteen were sent to the departments of culture and public education, six to the editorial offices of local newspapers and five to the organs of the Komsomol. ${ }^{64}$ On 28 March 1972 sixty-four letters were sent from Kaunas, and the KGB intercepted fifty-four of them at the post office. Only ten letters reached their addressees, who, out of fright, handed them over to the KGB. ${ }^{65}$ Many letters were written to foreign radio stations and state institutions, unmasking the essence of Soviet domestic and foreign policy and asking for support in the Lithuanian struggle for independence.

To prevent the forwarding of such letters and to discover their writers, a special KGB department controlled foreign correspondence. According to KGB data, the special sixth department checked half a million documents in 1958. Among them ca. 3,000 were addressed to foreign radio stations, and 25,000 documents were confiscated because they contained undesirable information. ${ }^{66}$ In 1959 the same department examined 2,627,275 documents. ${ }^{67}$ Those entering into

${ }^{64}$ LTSR KGB 19730330 pranešimas TSRS KGB (LSSR KGB report to USSR KGB, Mar. 30, 1973). LYA, f. K-1, ap. 10, b. 438, 1. 137-138.

${ }^{65}$ LTSR KGB 19721227 pažyma apie agentürinę bylą "Raskolniki" (LSSR KGB commentary on the 'Schismatics' agent case; Dec. 27, 1972). LYA, f. K-1, ap. 10, b. 438, 1. 149.

${ }^{66}$ LTSR KGB 1958 metų darbo ataskaita (LSSR KGB annual report, 1958). LYA, f. K-1, ap. 10, b. 253 , 1. 274-275.

${ }^{67}$ LTSR KGB 1959 mety̨ darbo ataskaita (LSSR KGB annual report, 1959). LYA, f. K-1, ap. 10, b. 255, 1. 18. 
correspondence with foreigners were subjected to special registration. In 1970 of the total number of 519,000 foreign letter writers 357,000 were on the books. ${ }^{68}$ The suspects were not only registered, their files contained the examples of their handwriting and other material, necessary for having them shadowed.

After the suppression of the armed resistance, the underground press remained practically the only means to express the nation's opposition to the invaders. Clandestine publications, the dissemination of leaflets, letter writing, etc., could be compared to the post-war armed resistance, which by their power to unmask Soviet policy hurt the occupiers no less than the armed struggle.

After the occupations of 1940 and 1944 attempts were made not only to destroy the economic and political structures of the country, but also to obliterate the historical past of the nation from her consciousness. A significant landmark in the history of Lithuania was February 16. The commemoration of this event was a major form of youth resistance to the Soviet regime. The ideas proclaimed in the Independence Act coincided with the objectives of many youth organizations. February 16 often figured in the names of resistance organizations. Already during the first Soviet occupation the celebration of Lithuania's Independence Day became a mass demonstration of patriotic orientation. Yellow-green-red tricolours fluttered in places, which were well seen and difficult to access, anti-Soviet leaflets and graffiti were frequent that day. In schools wall-newspapers issued by the Komsomol, and portraits of Bolshevik leaders were torn down, caricatures and anti-regime slogans were painted on the walls. Flags appeared in the most unbelievable places. In 1958 the members of 'Laisvę Lietuvai' hoisted a tricolour at a height of $80 \mathrm{~m}$ on the chimney of the Petrašiūnai power plant in Kaunas. A similar event took place in Klaipeda on 16 February 1970, when young workers of the paper and cellulose plant attached a $190 \times 99 \mathrm{~cm}$ flag with the inscription 'Sutraukysim vergijos pančius' (We shall shake off the shackles of slavery) to the lightningconductor at a height of $102 \mathrm{~m} .{ }^{69}$

Young people had some other ways to celebrate the 16 th of February, too. In the 1970s pupils of some schools used to

${ }^{68}$ LTSR LGB 1970 metų agentūrinio, operatyvinio ir tardymo darbo ataskaita (LSSR KGB annual report on agent, operational and interrogation work, 1970). LYA, f. K-1, ap. 10, b. 372, 1. 40.

${ }^{69}$ LTSR KGB 19700316 pranešimas TSRS KGB (LSSR KGB report to USSR KGB, Mar. 16, 1970). LYA, f. K-1, ap. 10, b. 377, 1. 24. 
wear national ties or self-made badges, they did not wear Soviet Young Pioneer ties, instead they wore ribbons with the colours of the Soviet Lithuanian flag, however, with its white stripe painted yellow, etc. Despite constant militia and KGB persecution, filming and arrests, young people laid flowers on the graves of the poet Maironis, the state patriarch Jonas Basanavičius, on the graves of the soldiers who fell in battle fighting for the independence of Lithuania and at historical monuments. Since 1975 this national holiday was associated increasingly also with the Nazi-Soviet pacts, the effects of which were disastrous for Lithuania, and with human rights and freedoms. Especially widespread was a half-open commemoration of the 70th anniversary of the re-establishment of Lithuania's independence in $1988 .{ }^{70}$ After five decades of terror and persecutions, the resistance to the Soviet regime gained momentum in 1989 . February 16 was celebrated officially again, and its symbol - the Lithuanian tricolour - again fluttered freely. The aspirations of the nation and its youth became a reality after half a century of occupation.

In youth resistance the celebration of the All Souls' Day, when people remembered not only their loved ones and relatives, but also those who died fighting for the country's freedom was particularly significant. Flowers were placed and candles were lit on the graves of the participants of the national rebirth and statesmen, of soldiers, killed in the wars for independence, the national anthem and patriotic hymns were sung in cemeteries. Repressive organs began their preparation for the All Souls' Day well in advance. The NKGB issued their special directives to the counties, recruited agents and followed the activity of the clergymen. The 13 October 1945 directive no. 59 of the USSR NKGB commissioner for Lithuania indicated the tasks of the NKVD and NKGB of the republic on that day in great detail:

'To give comprehensive instructions to the agents, in order to reveal in due course attempts to use religious holidays for anti-Soviet purposes. To arrest without delay persons intending to commit anti-Soviet actions. To set a task for the agents among the clergy to prevent any anti-Soviet manifestations.

${ }^{70}$ LTSR KGB 19880222 įsakymas Nr. 031 Dèl valstybès saugumo užtikrinimo rezultatų ryšium su buržuazinès Lietuvos nepriklausomybès paskelbimo 70-mečiu (LSSR KGB order No. 31 (Feb. 22, 1988) 'On the results of state security investigations of the 70th anniversary of the declaration of independence of bourgeois Lithuania'). LYA, f. K-1, ap. 10, b. 727, 1. 65-66. 
To warn the agents that they would be responsible for the use of religious holidays for anti-Soviet purposes. To keep the $N K V D-N K G B$, the militia and the liquidation battalions ready for action in case of possible mass excesses. To keep troops on red alert. To strengthen the agent shadowing of the priests. To send sufficient numbers of the agents and NKVD-NKGB officers dressed in civilian clothes to cemeteries and churches. ${ }^{71}$

The celebrations of the All Souls' Day in the mid-fifties acquired a distinct political character in Vilnius and Kaunas. They coincided with the political events in Poland and Hungary. In the disturbances during the holiday in 1956, 85 people were detained in Kaunas. ${ }^{72}$ Jonas Budrevičius, Grigorijus Piskunovas, Juozas Starkauskas and Algimantas Virbalas were arrested and convicted for the participation in the All Souls' Day demonstration. ${ }^{73}$

Neither repression nor law courts could subdue patriotic feelings and respect for those who sacrificed their lives for the freedom and independence of their country. On each All Souls' Day throughout all the years of Soviet occupation young people demonstrated their patriotic attitude and their determination to foster freedom ideals.

The death of Romas Kalanta, who burned himself to death in Kaunas in 1972, is a striking chapter in the Lithuanian youth resistance movement; the events related to his death and their subsequent development influenced the further course of the youth movement. This incident demonstrated a wide spectre of political viewpoints and served as a stimulus for the spread of resistance ideas among young people. According to official data, as many as 402 persons were arrested in Lithuania during Kalanta's funeral. Among them young workers constituted 47.7 per cent, students and pupils 29.6, employees 9.2 and young people who neither worked nor studied, made up 4.9 per

71 TSRS NKGB-NKVD igaliotinio Lietuvai 19451013 raštas LTSR NKVD ir NKGB komisarams, LTSR NKVD-NKGB operatyvinių sektorių, apskričių ir miestų viršininkams (Note of the USSR NKGB-NKVD commissioner to Lithuania, Oct. 13, 1945, to NKVD-NKGB commissars of LSSR and heads of operative sectors, counties and towns). LYA, f. K-1, ap. 18 , b. $64,1.88-89$.

${ }^{72}$ LTSR KGB 19561122 specialus pranešimas apie 1956 m. lapkričio 2 d. îvykius Kaune (Special report of LSSR KGB concerning events in Kaunas on Nov. 2, 1956; Nov. 22, 1956). LYA, f. K-1, ap. 3, b. 468, 1. 244-248.

${ }^{73}$ Ibid., 1. 243-248. 
cent; there were even collective farmers. Every fourth detainee was a member of the Komsomol. ${ }^{74}$ Among those arrested 99 persons were younger than 18 years old, and 77 were between 18 and $20 .{ }^{75}$ Thirty-three persons were brought to trial, and criminal proceedings were instituted against six detainees. ${ }^{76}$

Open resistance activity was suppressed after Kalanta's death. However, a wave of passive opposition swept through the country. Printed and hand-written copies of a poem dedicated to the self-immolation of Kalanta spread in Lithuania. The poem commemorating the deed called for the struggle against the Soviet power. The KGB collected 58 copies of the poem, interrogated 98 witnesses and requested the accounts of 77 persons. ${ }^{77}$

Young people commemorated the anniversary of Kalanta's death by distributing not only poems, but also leaflets. In 1974 a pupil from the secondary school in Alanta, Algimantas Andreika, organized a group of young people, which openly celebrated the anniversary of Kalanta's death, distributed leaflets and posters. ${ }^{78}$ To mark the anniversary in 1974 proclamations 'Lietuvos jaunime!' (Youth of Lithuania!) were disseminated in Vilnius. ${ }^{79}$ Young people cultivated the idea of honouring Kalanta's memory, issuing badges and pendants and organizing youth demonstrations on 14 May. Therefore, at the approach of the tragic anniversary the streets of the cities and towns of Lithuania were full of militiamen and members of public-order squads, and the KGB was on the alert. On 14 May students were not allowed to walk in Laisvès aleja - the principal avenue of Kaunas and to gather in other places, frequented by young people. On those days excursions to Kaunas from other cities were forbidden, and the movement of people in the garden of the Kaunas Theatre and other places of gathering was closely watched.

${ }^{76}$ Ibid., 1. 7.

${ }^{77}$ LTSR KGB tardymo skyriaus vyr. tardytojo majoro A. Vilimo 1974 1001 nutarimas nutraukti bylą (Decision to close the case by senior interrogator of the LSSR KGB Interrogation Section, Major A. Vilimas; Oct. 1, 1974). LYA, f. K-1, ap. 43, b. 189, 1. 232-235.

${ }^{78}$ LTSR KGB 19760812 pranešimas TSRS KGB (Report of LSSR KGB to USSR KGB, Aug. 12, 1976). LYA, f. K-1, ap. 10, b. 193, 1. 98.

${ }^{79}$ LTSR KGB medžiaga apie atsišaukimų išplatinimą 19740514 (Materials of LSSR KGB on the dissemination of leaflets on May 5, 1974). LYA, f. K-1, ap. 43, b. 193, 1. 185. 


\section{The Suppression of Youth Resistance}

The members of youth resistance organizations were subjected to the same harsh forms of repression as any other participants of the resistance movement, i.e., interrogation, tortures in the basements of the KGB, deportation of other members of their families, etc. The NKGB directive no. 12 of 25 January 1945appointed the task of determining to what degree "the bourgeois nationalists' were supported by the youth. In the course of the action the following issues had to be taken into account:

'1. The investigation of any materials, related to the youth in order to establish to what extent the bourgeois nationalists relied on the support of the youth.

2. The elimination anti-Soviet youth groups and organizations. The trend of research is to determine the contacts of young people with the arrested members.

3. The preparation for the recruitment of the arrested members of the anti-Soviet groups in order to disclose their anti-Soviet formations', ${ }^{80}$

In his letter of 5 June 1945 to the NKGB of the USSR, the Commissar of the NKGB of the LSSR, Aleksandras Guzevičius, stressed that 'the organization of the agent and operative work of watching the youth in the conditions of the LSSR is of exceptionally great importance', because 'after the reconstruction of the Soviet power the reactionary part of the youth took up the struggle against the Soviet power and became the organizing nucleus of anti-Soviet nationalistic underground organizations' ${ }^{81}$ The KGB departments of towns and counties were instructed to treat the persecution of the intelligentsia and the youth as a separate activity. Experienced NKGB workers were appointed for that work. According to a special plan, agents had to be recruited in secondary schools and institutions of higher education, the organs of the Communist party and Soviet institutions had be informed about the activity of disclosed organizations, and corresponding measures had to be taken to

${ }^{80}$ LTSR NKGB 19450719 pranešimas TSRS NKGB 2 valdybos viršininkui 'Agentūrinio ir operatyvinio darbo padetis tarp jaunimo Vilniuje ir mūsų tolimesnès priemonés' (LSSR NKGB report to the head of Section 2 of the USSR NKGB, July 19, 1945, 'The state of agent and operative activity among the youth of Vilnius and our further measures'). LYA, f. K-1, ap. 10, b. $22,1.87-88$.

${ }^{81}$ LTSR NKGB 19450605 paaiškinamasis raštas (Explanatory note of LSSR NKGB, June 5, 1945). LYA, f. K-1, ap. 10, b. 20, 1. 237. 
'strengthen the agitation and educational work among the students' ${ }^{82}$

In order to intimidate the youth, techniques of psychological pressure were applied to the members of the organizations; the whole complex of those measures was referred to as a preventive check-up. Its implementation was entrusted to the Party and Komsomol organs and to the more reliable fellow workers.

KGB preventive measures did not always obtain the required result. Despite those measures the youth continued their activity, and new members appeared after the example of their like-minded friends. Therefore, the KGB not merely endeavoured to suppress the opposition, it also concealed the information about its existence, presenting resistance facts, reaching the general public, as accidental, and as 'recurrences of insane ambitions and unbalanced mind.' Measures of mental coercion were combined with those of physical pressure. Those known as participants of anti-Soviet activities were obstructed or prevented from performing their immediate duties. According to the requirement of the KGB young people opposed to the regime had to be barred from entering institutes of higher education.

From the very first days of the occupation attempts were made to construct an enormous network of agents to suppress resistance. Throughout all the years of the Soviet regime, 109,000 agents were registered, and many of them were young people. ${ }^{83}$ Correspondingly, pressure was also exerted on the youth, loyal to the regime, and on the members of the Komsomol. In order to reveal the mood of young people, the KGB penetrated into various youth structures, using the services of the individuals, loyal to the regime.

The Soviets spared no propaganda and ideological efforts to turn young people into a docile tool of the regime, which could support and strengthen it. Therefore, so much attention was paid to the subjugation of the youth to the Soviet system, to their indoctrination with Communist ideology and the formation the Sovietized political structures among young people. The extent of that campaign is illustrated by youth involvement in the

${ }^{82}$ Ibid., 1. 249.

${ }^{83}$ Juozas Paranauskas. KGB agentūros verbavimas ir agentų kategorijos. Lietuvos gyventojų genocido ir rezistencijos tyrimo instituto darbai. Vilnius, t. 2, 1996, 49. 
Komsomol. In the period of the Soviet regime 1,579,000 young men and women were made members of that organization; the majority of them (76 per cent) were students.

Economic and political processes taking place in the towns and in the countryside were also used for the Sovietization of young people. The Communist Party and the Komsomol aimed at transforming the process of production into never-ending ideological campaigns and the young workers themselves (they were in the majority) into 'real Communists'. Publicizing the heroic deeds of the young, the regime intended to create a favourable atmosphere for itself. On the other hand, focusing the attention of youth people to the solution of economic problems was a means of diverting their attention from the political problems of the Lithuanian nation.

The resistance activity of youth organizations left a deep imprint in the history of the heroic struggle for national independence, and by fostering national consciousness it paved the way for the re-establishment of Lithuanian statehood. The interest of young people in their history did not abate during the whole period of the Soviet occupation and together with the partisan movement it was a fundamental factor in stimulating the resistance movement.

The Communist regime persecuting the participants of the resistance did not merely carry out repression but also created a social environment, ensuring the existence of the regime, paying attention to both the suppression of the resistance and the formation of Communist youth structures, propagation of Bolshevik ideology and the introduction of the Soviet way of life.

\section{Conclusions}

The Sovietization of Lithuanian social and political life after the occupation and annexation of the country in 1940 and 1944 provoked the resistance of the nation and of its youth. Various circles and groups sprang up, they consisted mostly of students of secondary and higher schools, leaders and rank and file members of the proscribed organizations. The resistance movement, begun in the first years of the Soviet and Nazi occupations, continued under the circumstances of the second Soviet invasion.

This paper deals with the organization of youth resistance, the influence of the partisan movement and other factors, 
instrumental in stimulating the opposition to the regime. Events, relating to the death of Romas Kalanta and significantly affecting the further course of the youth movement, are also dealt with in the study.

The members of youth organizations, as well as any other participants of the resistance were subjected to the same brutal repressive measures. Methods of psychological and mental coercion were used for the intimidation of the youth, and the network of agents was extended.

The Soviet authorities made great ideological attempts to make young people an obedient tool of the regime. Particular attention was paid to strengthening the structures of the Komsomol as instruments of spiritual indoctrination.

Despite ever increasing ideological and physical pressure the resistance of the youth to the Soviet regime did not subside. Every year new organizations sprang up. By preliminary estimates, the KGB uncovered no less than 450 organizations during the entire period of the Soviet power in Lithuania. 